\title{
Pedagogical Perceptions of Iranian University Instructors and Students on their Academic Technological Literacy: Reflections and Restrictions
}

\author{
Mahnaz Azad \\ East Tehran Branch, Islamic Azad University, Iran
}

\begin{abstract}
Recently, several studies have examined the influence of technology use within the educational settings pointing that the perception of the students as well as the instructor towards technology use is indicative of how well technology might be integrated in instruction. Therefore, this study was designed to explore university lecturers' perceptions toward instructional technology, their actual versus perceived ICT literacy, the extent to which they integrate technology in their instruction and the challenges they might face in successfully integrating instructional technology in academic context. The population consisted of 711 male and female university students studying in different majors including Science, Engineering, Humanities, and Art. Also, 111 instructors teaching different fields took part in the data collection process. Two different questionnaires were devised for the instructors and the students. Moreover, for gathering more reliable data, a semi-structured interview was conducted with 51 instructors and 135 students together with an observation to give more depth to the data. The data were analyzed both qualitatively and quantitatively. The study concluded that university lecturers had positive attitude toward ICT and were moderately proficient in the use of ICT while university students had different levels of ICT knowledge and were mostly willing to experience digital learning. However, the limitations mentioned in the study show an urgent need for some measures to be taken for continuous training of university lecturers in ICT which in turn leads to training more knowledgeable digital generation.
\end{abstract}

\section{Introduction}

Information and communications technologies (ICT) have become pervasive in modern societies as tools for transforming educational systems as well as supporting economic development in agriculture, health and education, and connecting communities, teachers and students [1].
In general, ICT literacy and digital literacy have been conceptualized in relation to a wider range of technologies than ICT literacy but the terms overlap to a considerable extent and are often used interchangeably but the emphasis of most of them has been on computer applications because computers (and similar devices) have been regarded as an important element of ICT.

ICT literacy is based on the principles from the field of information literacy and focused on the use of these information technologies to locate and collect information, evaluate information, transform (analyze and create) information and communicate ideas [2]. [2] argued that, although these processes have been seen traditionally as a part of information literacy, they have been substantially changed by digital technologies given the volume and variable quality of digital information.

Considering the growing importance of technology implications for educational and economic development in the context of global economy, there is a need for its development among university lecturers and students. In our country Iran, technology (unlike science, mathematics, and even engineering) is not a discrete discipline taught formally in our schools. At best, technology skills are integrated in elementary and secondary schools as students use related skills to conduct school activities and projects in core subject areas. At worst, technology skills (i.e., information technology literacy skills) are taken for granted under the premise that technology is now part of growing up and in almost all aspects of living and work and thus it is not necessary to be addressed through formal education. Research studies show that graduating university students lack specific computer skills (e.g. [3][4]).

Additionally, technology-related skills are partially taught in career and technical education programs as basic core skills in business technology programs and as a part of other technology-based occupational programs. Students study in related 
fields, learn some basic technology skills including rudimentary computer skills such as proper keyboarding skills and integrated software applications using Microsoft Office Software (i.e., Word, Excel, PowerPoint, and Access), etc. However, the point is that most of them learn the computer skills at the theoretical levels and cannot apply them in practical modes.

At the other side of the coin, the instructors of the universities are required to be technologically literate and at least should be able to use basic technology and computer programs as they need in their classrooms. Unfortunately, however, most university instructors are not aware of these basic requirements and follow traditional procedures during their instruction. The issue though, is the fact that although, the value of information technology skills has been noted as critical for further education and work, there is little research clarifying what they really are to guide further study.

\section{Research on Information Technology Skills}

Research studies on specific computer technology skills found that students entering work and/or college lack the necessary proficiency skills required to use computers ([5][6][7][8]). For instance, [9] made an investigation on information technology skill of elementary school teachers. The results showed that the status of teachers 'information literacy skills was not appropriate. Another finding showed that there was a positive and significant relationship between the amount of hours of using the Internet per week and the amount of free weekly reading time by teachers with their information literacy skills. It was also found that there was a negative and significant relationship between the subjects' age and their level of information literacy.

Moreover, [10] investigated the relationship between teachers 'technology education literacy and students' academic achievement in the elementary science lesson in the education department. The results of the research showed that there is a significant relationship between the technology literacy of teachers and students' academic achievement in the elementary sciences, and the use of intelligent display has the most correlation with the academic achievement of learners in the experimental sciences.

Furthermore, some studies show that students entering higher education believe that their technology skills are more refined than what they actually are due, perhaps, to the idea of frequent use in daily life. For example, [11] collected data from incoming freshman students and found that perceptions of attained computer technology skills were higher than when they graduated four years later. In turn, [12] while studying the growing importance of computer technology literacy in higher education found that students performed better academically with more basic and intermediate computer application skills. The Katz and Macklin study concluded that student's perceptions of computer technology skills were higher due to the interactions with the Internet and that integrating technology with learning specific computer software applications improved the quality of computer skills. The message was that integrating technology is not enough; educators must instruct students on how to use specific computer tool-based software used within the content being taught.

Generally, the body of literature on proficiency and extent of use of computer and information technology skills at work and in college is limited. Available research suggests that student perceptions do not always signify that they have the knowledge to perform the tasks to integrate technology that is expected. Thus, further research is needed to contribute to this line of inquiry. With this point in mind, it is important to determine to what extent our university instructors and students are aware of information technology skills and how much they actually use this knowledge in education and work. Thus, this research is going to probe on the issue with the aim to help improve university instructors and students teaching and learning quality respectively.

\section{Research Questions}

To address the purpose of the study, the following research questions guided the study inquiry:

1. To what extent our university instructors are technologically literate from their own and their students' perspectives?

2. To what extent our university students are technologically literate from their own and their teachers' perspectives?

3. How really competent are our university instructors in using technological tools?

4. Do the university lecturers' different fields of study affect their technological literacy?

5. Is there a difference in self-assessed technological literacy skills perceived by university lecturers and students and their real technological competency?

6. For what purposes (personal and educational) do university instructors and students use technology tools?

7. To what extent do university instructors use technology in their classroom? 
8. To what extent do university instructors encourage the student to use technology in learning and doing their assignment?

9. What are the limitations, if any, in using technology in university classes?

\section{Method}

The purpose of the present study was to identify how much university instructors and students possess the basic technology literacy skills needed for successful participation in further education and/or work. In the context of the proposed study, information technology literacy is defined as basic skills using computers, word processing, spreadsheets, presentation software, databases, graphic software, networking, electronic information and telecommunications.

\section{Research Design}

To address the research questions and conduct the study, a mixed-method design was used to gather perspectives of university instructors and students.

\section{Participants}

The target population for participation in this study consisted of 711 male and female university students studying in different majors including Science, Engineering, Humanities, Art, etc. at BA and MA levels. Also, 111 instructors teaching different fields took part in the data collection process. All the participants were chosen from Islamic Azad University.

\section{Instruments}

In order to conduct this study, a triangulation of data was used: Two questionnaires were used to gather data. The first one was a technology literacy questionnaire adapted and devised for the students comprising 17 items, each with some subcategories. The second questionnaire was devised for the instructors consisting of 12 items. Participants were required to answer the questions and fill in the tables as explained. The information gathered through the questionnaires consisted of their demographic information, their field of study, as well as some information regarding their degree of familiarity with computer technology. Also, some detailed information was collected via the questionnaires. The questionnaires were adapted from different questionnaires available in the internet and related studies. They were devised in a way to address basic computer and internet skills. After piloting the questionnaires, the reliability of the adapted questionnaires were estimated to be 0.82 and 0.87 for the students' and instructors' questionnaires respectively.

Furthermore, for gathering more reliable data, a semi-structured interview was conducted with 51 instructors and 135 students. The purpose was to give more depth to the information accumulated and probe on the probable distance between the perceived and actual information gathered through the questionnaires. The validity of the questions had already been confirmed by five experts. Moreover, the university instructors were informed that during the term, the classes of some of the instructors would be observed randomly to see to what extent they were willing and competent to use the technology in their classes.

\section{Data Collection Procedures}

Participants were informed verbally about the voluntary nature of their participation and that thedata would be kept and analyzed confidentially. As recommended by other researchers, all participants were given one week to respond the questionnaire specified for them [14]. Also, the questionnaires were emailed to the participants if necessary. Moreover, the participants were asked to identify technology skills needed at work or in college and list any additional skills they felt are needed but not included in the list relevant to each of the domains. Furthermore, 135 students and 51 instructors were interviewed individually after completing the questionnaires in their pre-determined time. Also, for the purpose of observational analysis, some of the university instructors' classes were observed randomly with their prior consent to set the stage for further analyses.

\section{Data Analysis}

\subsection{Quantitative Phase of the Study}

The present study explored Iranian university lecturers and students' computer literacy. To achieve these objectives, two questionnaires were developed and distributed among 111 university lecturers and 711 students. The results are discussed below.

\subsubsection{Exploring the First Research Question}

To what extent our university instructors are technologically literate from their own perspective?

According to Table 1, the majority of the respondents $(\mathrm{n}=91,82 \%)$ believed that their technological literacy was good. Another 4.5 percent estimated their computer literacy as excellent. On the other hand; $11.7 \%$ believed that their computer 
literacy was adequate, and another 1.8 percent rated their computer literacy as weak.

Table 1. Frequencies and percentages of lecturers' perception of their own computer literacy

\begin{tabular}{lcc}
\hline & Frequency & Percent \\
\hline Weak & 2 & 1.8 \\
Enough & 13 & 11.7 \\
Good & 91 & 82.0 \\
Excellent & 5 & 4.5 \\
Total & 111 & 100.0 \\
\hline
\end{tabular}

\subsubsection{Exploring the Second Research Question}

To what extent our university students are technologically literate from their own perspective?

As Table 2 presents, the majority of the respondents $(n=327,46 \%)$ believed that their technological literacy was adequate. This was followed by 183 students $(25.7 \%)$ who rated their computer literacy as good. Another 7.3 percent believed that their computer literacy was excellent, while 21 percent rated their computer literacy as weak.

Table 2. Frequencies and percentages of university students' perception of their own computer literacy

\begin{tabular}{lcc}
\hline & Frequency & Percent \\
\hline Weak & 149 & 21.0 \\
Enough & 327 & 46.0 \\
Good & 183 & 25.7 \\
Excellent & 52 & 7.3 \\
Total & 711 & 100.0 \\
\hline
\end{tabular}

\subsubsection{Exploring the Third Research Question}

How really competent are our university instructors in using technological tools?

Considering Table 3, the results indicated that the majority of the teachers; i.e. 55.9 percent; estimated their internet skills as good. Another $22.5 \%$ believed that their internet literacy was excellent, while 21.6 percent rated their internet skills as adequate.
The results also indicated that the majority of the teachers; i.e. 46.8 percent, estimated their typing skills as good. Another $25.2 \%$ believed that their typing skill was excellent. On the other hand, 17.1 percent rated their typing skills as adequate, and another 2.7 percent estimated their skill as weak.

Table 3. Frequencies and percentages of lecturers' estimation of their ability to use technological tools

\begin{tabular}{llcc}
\hline & & Frequency & Percent \\
\hline \multirow{4}{*}{ Internet } & Enough & 24 & 21.6 \\
Literacy & Good & 62 & 55.9 \\
& Excellent & 25 & 22.5 \\
& Total & 111 & 100.0 \\
\hline \multirow{7}{*}{ Typing Skill } & Weak & 3 & 2.7 \\
& Enough & 19 & 17.1 \\
& Good & 52 & 46.8 \\
& Excellent & 28 & 25.2 \\
& Missing & 9 & 8.1 \\
& Total & 111 & 100.0 \\
\hline
\end{tabular}

\subsubsection{Exploring the Fourth Research Question}

Do the university lecturers' different fields of study affect their technological literacy?

Table 4 shows the frequencies, percentages and standardized residuals for the teachers' computer literacy at humanity, basic sciences, architecture and technical science faculties. The results indicated that majority of humanity $(83.1 \%)$, basic sciences $(66.7$ $\%)$, architecture (100\%) and technical sciences instructors $(100 \%)$ believed that their computer literacy was good and or excellent.

The results also showed that none of the Std. Residuals were higher than +/- 1.96 except for the percentages of basic science teachers who rated their computer literacy as weak $(11.1 \%$, Std. Residual = $2.9>1.96)$.

That is to say, the teachers in basic sciences, more than other fields of study, significantly claimed that their computer literacy was weak. 
Table 4. Frequencies, percentages and std. residuals; computer literacy by faculties (Instructors)

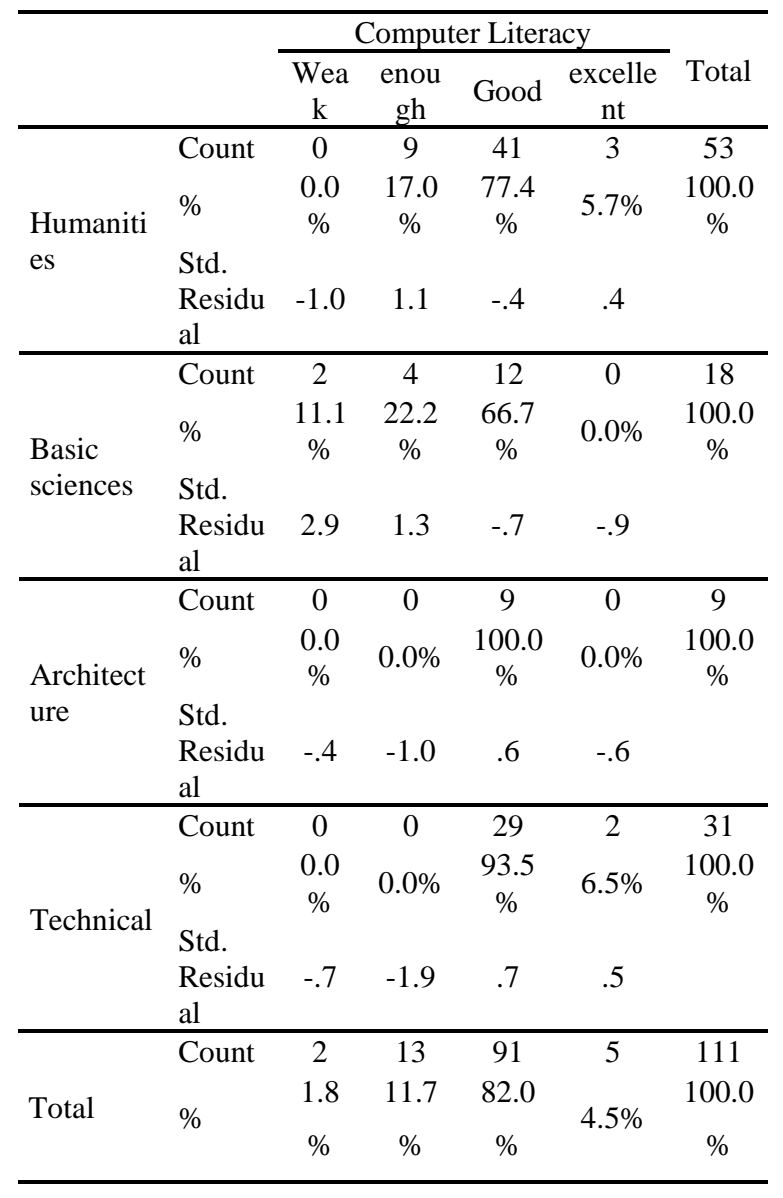

Table 5 refers to the results of the analysis of chisquare. The results $\left(\chi^{2}(9)=23.40, \mathrm{p}=.005\right)$ indicated that there were significant differences between the four groups' of teachers' computer literacy. As it was discussed above, the basic science teachers, significantly more than other faculties, believed that their computer literacy was weak. The effect size for the chi-square was .435 which represent a moderate effect size (Cramer's V $=.252$, Cohen's $\mathrm{W}=.435$ representing a moderate effect size) [15]. Thus, the null-hypothesis as "the university lecturers' different fields of study did not significantly affect their technological literacy" was rejected.

Table 5. Chi-Square tests; computer literacy by faculties (Instructors)

\begin{tabular}{lccc}
\hline & Value & df & $\begin{array}{c}\text { Asymptotic } \\
\text { Significance (2-sided) }\end{array}$ \\
\hline Pearson Chi-Square & $21.122^{\mathrm{a}}$ & 9 & .012 \\
Likelihood Ratio & 23.403 & 9 & .005
\end{tabular}

\begin{tabular}{lccc} 
Linear-by-Linear & 3.471 & 1 & .062 \\
Association & & & \\
N of Valid Cases & 111 & & .012 \\
Cramer's V & .252 & & \\
\hline
\end{tabular}

a. 11 cells $(68.8 \%)$ have expected count less than 5 .

The minimum expected count is .16.

Chi-square (see Table 5) assumes that no more than 20 percent of cells have expected frequencies less than 5, while, almost 69 percent of cells in Table 5 have expected frequencies less than 5 . To overcome the problem, the Fisher's exact test should be computed. As displayed in Table 6, the results of the Fisher's exact test $(16.39, \mathrm{p}=.015)$ indicated that the significant result of the chi-square testwas not affected by the cell frequencies less than five. Thus, the fifth null hypothesis was correctly rejected.

Table 6. Chi-square tests plus Fisher's Exact Test

\begin{tabular}{|c|c|c|c|c|c|c|}
\hline & Value & $\begin{array}{l}\mathrm{d} \\
\mathrm{f}\end{array}$ & $\begin{array}{c}\text { Asymptoti } \\
\text { c } \\
\text { Significanc } \\
\text { e (2-sided) }\end{array}$ & $\begin{array}{c}\text { Exac } \\
\text { t Sig. } \\
(2- \\
\text { sided } \\
)\end{array}$ & $\begin{array}{c}\text { Exac } \\
\text { t Sig. } \\
(1- \\
\text { sided } \\
)\end{array}$ & $\begin{array}{c}\text { Point } \\
\text { Probabilit } \\
y\end{array}$ \\
\hline $\begin{array}{l}\text { Pearson } \\
\text { Chi- } \\
\text { Square }\end{array}$ & $\underset{\mathrm{a}}{21.122}$ & 9 & .012 & .018 & & \\
\hline $\begin{array}{l}\text { Likelihoo } \\
\text { d Ratio } \\
\text { Fisher's }\end{array}$ & 23.403 & 9 & .005 & .003 & & \\
\hline $\begin{array}{l}\text { Exact } \\
\text { Test }\end{array}$ & 16.398 & & & .015 & & \\
\hline $\begin{array}{l}\text { Linear- } \\
\text { by-Linear } \\
\text { Associatio } \\
n \\
\mathrm{~N} \text { of }\end{array}$ & $3.471^{\mathrm{b}}$ & 1 & .062 & .072 & .035 & .011 \\
\hline $\begin{array}{l}\text { Valid } \\
\text { Cases }\end{array}$ & 111 & & & & & \\
\hline
\end{tabular}

\subsubsection{Exploring the Fifth Research Question}

Is there a difference in self-assessed technological literacy skills perceived by university lecturers and students?

Table 7 presents the frequencies, percentages and standardized residuals for the university lecturers and students' perceived computer literacy. The results indicated that:

- University lecturers significantly estimated their computer literacy as weak $(1.8 \%$, Std. Residual = $4.1>-1.96)$, less than students $(21 \%$, Std. Residual $=$ 1.6). 
- University lecturers significantly estimated their computer literacy as enough $(11.7 \%$, Std. Residual $=$ $-4.9>-1.96)$, less than students (46\%, Std. Residual $=1.9)$.

Table 7. Frequencies, percentages and std. residuals; computer literacy by groups

\begin{tabular}{|c|c|c|c|c|c|c|}
\hline & & \multicolumn{4}{|c|}{ Choices } & \multirow[b]{2}{*}{ Total } \\
\hline & & $\begin{array}{c}\text { Wea } \\
\mathrm{k}\end{array}$ & $\begin{array}{c}\text { Enoug } \\
\mathrm{h}\end{array}$ & $\begin{array}{c}\text { Goo } \\
\text { d }\end{array}$ & $\begin{array}{c}\text { Excelle } \\
\text { nt }\end{array}$ & \\
\hline \multirow{3}{*}{$\begin{array}{l}\text { Lecture } \\
\text { rs }\end{array}$} & Count & 2 & 13 & 91 & 5 & 111 \\
\hline & $\%$ & $1.8 \%$ & $11.7 \%$ & $\begin{array}{c}82.0 \\
\%\end{array}$ & $4.5 \%$ & $\begin{array}{c}100.0 \\
\%\end{array}$ \\
\hline & $\begin{array}{l}\text { Std. } \\
\text { Residu } \\
\text { al }\end{array}$ & -4.1 & -4.9 & 8.9 & -1.0 & \\
\hline \multirow{3}{*}{$\begin{array}{l}\text { Student } \\
\mathrm{s}\end{array}$} & Count & 149 & 327 & 183 & 52 & 711 \\
\hline & $\%$ & $\begin{array}{c}21.0 \\
\%\end{array}$ & $46.0 \%$ & $\begin{array}{c}25.7 \\
\%\end{array}$ & $7.3 \%$ & $\begin{array}{c}100.0 \\
\%\end{array}$ \\
\hline & $\begin{array}{l}\text { Std. } \\
\text { Residu } \\
\text { al }\end{array}$ & 1.6 & 1.9 & -3.5 & .4 & \\
\hline \multirow[b]{2}{*}{ Total } & Count & 151 & 340 & 274 & 57 & 822 \\
\hline & $\%$ & $\begin{array}{c}18.4 \\
\%\end{array}$ & $41.4 \%$ & $\begin{array}{c}33.3 \\
\%\end{array}$ & $6.9 \%$ & $\begin{array}{c}100.0 \\
\%\end{array}$ \\
\hline
\end{tabular}

- University students significantly estimated their computer literacy as good $(25.7 \%$, Std. Residual $=-$ $3.5>-1.96)$ than lecturers $(82 \%$, Std. Residual $=8.9$ $>1.96$ ).

- Finally, there was not any significant difference between university lecturers $(4.5 \%$, Std. Residual = $1<-1.96)$ and students' $(7.3 \%$, Std. Residual $=.4<$ 1.96) ratings of the computer literacy as excellent.

Table 8 displays the results of the analysis of chisquare. The results $\left(\chi^{2}(3)=138.66, \mathrm{p}=.000\right)$ indicated that there were significant differences between the university lecturers and students' perceptions of their computer literacy. As it was discussed above, university lecturers significantly less than students estimated their computer literacy as weak or enough, and students' perception of their computer literacy was significantly less than instructors. The effect size for the chi-square was .411 which represent a large effect size (Cramer's V $=.411$, Cohen's $\mathrm{W}=.581$ representing a large effect size) [15]. Thus, the null hypothesis as "there was not any significant difference in self-assessed technological literacy skills perceived by university lecturers and students" was rejected.
Table 8 . Chi-square tests; computer literacy by group

\begin{tabular}{lccc}
\hline & Value & df & $\begin{array}{c}\text { Asymptotic } \\
\text { Significance (2- } \\
\text { sided) }\end{array}$ \\
\hline $\begin{array}{l}\text { Pearson Chi- } \\
\text { Square }\end{array}$ & $138.660^{\mathrm{a}}$ & 3 & .000 \\
Likelihood Ratio & 136.917 & 3 & .000 \\
Linear-by-Linear & 65.647 & 1 & .000 \\
Association & 822 & & .000 \\
N of Valid Cases & .411 & & \\
Cramer's V &
\end{tabular}

a. 0 cells $(0.0 \%)$ have expected count less than 5 .

The minimum expected count is 7.70 .

\subsection{Quantitative Phase of the Study}

After addressing the five research questions related to the quantitative phase of this study, the remaining four research questions were analyzed qualitatively due to their nature. However, as it was mentioned before, 135 students and 51 instructors from different fields of study were selected and interviewed and then the results were analyzed using the frequency count and percentage of the responses. The results are presented in Tables 9 and 10 respectively.

\subsubsection{Exploring the Sixth Research Question}

For what purposes (personal and educational) do university instructors and students use technology tools?

According to the interview conducted on the students and the instructors, about $9 \%$ of the instructors have never used technology tools in their classes for teaching or even for assigning homework to the students. This is while around $49.5 \%$ of the instructors claimed that they have always used technology in their teaching through using power point, video projector, computer aids and so forth. Moreover, $40 \%$ of the instructors asserted that they didn't use technology tools in their classes due to lack of facilities or time, but they assign final projects for the students requiring them to surf the net or review the journals. 
Table 9. Interview with the students

\begin{tabular}{|c|c|c|c|c|}
\hline & Questions & Yes & No & No answer \\
\hline 1 & Do you think using technological tools is effective in learning? & $\begin{array}{l}90 \% \\
(121) \\
\end{array}$ & $\begin{array}{l}10 \% \\
(13)\end{array}$ & 1 \\
\hline 2 & Do you use computer or/and technological tools in doing projects? & $\begin{array}{l}70 \% \\
(94) \\
\end{array}$ & $\begin{array}{l}28 \% \\
(37) \\
\end{array}$ & 4 \\
\hline 3 & $\begin{array}{l}\text { Do your instructors encourage you to use digital tools to do assignments and/or term- } \\
\text { projects? }\end{array}$ & $\begin{array}{l}45 \% \\
(60)\end{array}$ & $\begin{array}{l}50 \% \\
(67)\end{array}$ & 8 \\
\hline 4 & Do instructors allocate extra marks for computer-based projects or internet search? & $\begin{array}{l}38 \% \\
(51) \\
\end{array}$ & $\begin{array}{l}57 \% \\
(76) \\
\end{array}$ & 8 \\
\hline 5 & Do you think your instructors need computer literacy? & $\begin{array}{l}90 \% \\
(121)\end{array}$ & $\begin{array}{l}10 \% \\
(13)\end{array}$ & 1 \\
\hline 6 & Do instructors use computer or technological tools in their lesson? & $\begin{array}{l}35 \% \\
(47)\end{array}$ & $\begin{array}{l}60 \% \\
(81) \\
\end{array}$ & 7 \\
\hline 7 & Do you think your instructors possess enough ICT literacy? & $\begin{array}{l}66 \% \\
(89)\end{array}$ & $\begin{array}{l}30 \% \\
(40)\end{array}$ & 6 \\
\hline 8 & Is there any specific software necessary to be learned by the students in your field? & $\begin{array}{l}58 \% \\
(78) \\
\end{array}$ & $\begin{array}{l}34 \% \\
(45)\end{array}$ & 12 \\
\hline 9 & $\begin{array}{l}\text { Do students in your field are obliged to learn a specific technological tool/ computer } \\
\text { program? If yes, do instructors help students learn? }\end{array}$ & $\begin{array}{l}62 \% \\
(83)\end{array}$ & $\begin{array}{l}35 \% \\
(47)\end{array}$ & 5 \\
\hline 10 & $\begin{array}{l}\text { Do you have an extra training to learn how to work with the specific software in your } \\
\text { field? }\end{array}$ & $\begin{array}{l}10 \% \\
(13)\end{array}$ & $\begin{array}{l}90 \% \\
(121) \\
\end{array}$ & 1 \\
\hline 11 & $\begin{array}{l}\text { Do you think using computer or technological tools can encourage students to learn } \\
\text { effectively? }\end{array}$ & $\begin{array}{l}88 \% \\
(118)\end{array}$ & $\begin{array}{l}10 \% \\
(13)\end{array}$ & 4 \\
\hline
\end{tabular}

Table 10. Interview with the instructors

\begin{tabular}{|c|c|c|c|c|}
\hline \multirow{2}{*}{\multicolumn{2}{|c|}{ Questions }} & \multirow{3}{*}{$\begin{array}{c}\text { Yes } \\
79 \% \\
(40)\end{array}$} & \multirow{3}{*}{$\begin{array}{c}\text { No } \\
20 \% \\
(10)\end{array}$} & \multirow{3}{*}{$\begin{array}{c}\text { No Answer } \\
\text { Less than } \\
1 \% \\
(1)\end{array}$} \\
\hline & & & & \\
\hline 1 & Do you think using computer/technological tools is effective in teaching? & & & \\
\hline 2 & Do you use computer or/and technological tools in teaching? & $\begin{array}{l}32 \% \\
(16) \\
\end{array}$ & $\begin{array}{l}65 \% \\
(33) \\
\end{array}$ & $\begin{array}{l}3 \% \\
(2)\end{array}$ \\
\hline 3 & $\begin{array}{l}\text { To what extent do you encourage students to use digital tools to do assignments and/or } \\
\text { term- projects? }\end{array}$ & $\begin{array}{l}80 \% \\
(40)\end{array}$ & $\begin{array}{l}20 \% \\
(10)\end{array}$ & $\begin{array}{l}\text { Less than } \\
1 \%(1)\end{array}$ \\
\hline 4 & Do you allocate extra marks for computer-based projects or internet search? & $\begin{array}{l}20 \% \\
(10)\end{array}$ & $\begin{array}{l}80 \% \\
(40)\end{array}$ & $\begin{array}{l}\text { Less than } \\
1 \%(1)\end{array}$ \\
\hline 5 & In your view, How much do students need computer literacy? & $\begin{array}{l}70 \% \\
(35) \\
\end{array}$ & $\begin{array}{l}30 \% \\
(15)\end{array}$ & $\begin{array}{c}\text { Less than } \\
1 \%(1)\end{array}$ \\
\hline 6 & Is there any specific software necessary to be learned by the students in your field? & $\begin{array}{l}74 \% \\
(37) \\
\end{array}$ & $\begin{array}{l}23 \% \\
(12)\end{array}$ & $\begin{array}{l}3 \% \\
(2)\end{array}$ \\
\hline 7 & $\begin{array}{l}\text { Do you have your students use a specific technological tool/ computer program for your } \\
\text { assignments? }\end{array}$ & $\begin{array}{l}79 \% \\
(40)\end{array}$ & $\begin{array}{l}20 \% \\
(10)\end{array}$ & $\begin{array}{l}\text { Less than } \\
1 \%(1)\end{array}$ \\
\hline 8 & $\begin{array}{l}\text { Do you have an extra training for the students to learn how to work with the specific } \\
\text { software in your field? }\end{array}$ & $\begin{array}{c}15 \% \\
(8)\end{array}$ & $\begin{array}{l}85 \% \\
(43)\end{array}$ & 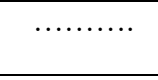 \\
\hline \multirow[t]{2}{*}{9} & $\begin{array}{l}\text { Do you think using computer or technological tools can encourage students to learn } \\
\text { effectively? }\end{array}$ & $\begin{array}{l}100 \% \\
(51)\end{array}$ & $\begin{array}{c}\ldots \ldots \\
\ldots\end{array}$ & $\cdots$ \\
\hline & & High & $\begin{array}{c}\text { Mode } \\
\text { rate }\end{array}$ & Weak \\
\hline 10 & How do you evaluate your students' computer literacy? & $\begin{array}{l}20 \% \\
(11) \\
\end{array}$ & $\begin{array}{c}10 \% \\
(5)\end{array}$ & $\begin{array}{l}70 \% \\
(35) \\
\end{array}$ \\
\hline 11 & $\begin{array}{l}\text { How do you think instructors will be encouraged to use computer or technological tools in } \\
\text { teaching? }\end{array}$ & \multicolumn{3}{|c|}{ To be explained below } \\
\hline
\end{tabular}


On the other side of the coin, all the students believed that they were using technology tools through their mobile phones for joining chatrooms and social channels as well as watching movies on-line. However, regarding the use of technology tools for learning, around $18 \%$ of them asserted that they used some software required for their classes such as Autocat, 3Dmax, CTT, CT, Excel and the like. The other students claimed that they used office software during the term for some classes. Around $42 \%$ of them asserted that power point is not a useful tool for teaching and that they couldn't learn in the classes in which the instructors used power point. About 3\% of the students claimed that they didn't know what technology tools were and they had never used/ experienced them.

\subsubsection{Exploring the Seventh Research Question}

To what extent do university instructors use technology in their classroom?

According to the data gathered from the instructors' self-report, about $45 \%$ of them had never used technology in their classes. It was because they thought technology was not applicable for the subject they taught or the facilities were not prepared in the classroom. Furthermore, some of them (around 17\%) believed that the use of any sort of technology in the classroom was a waste of time and that the class time should be allocated to traditional type of instruction. Although, $38 \%$ of the instructors asserted that they have used technology tools in their classes for some years. Some of them had just used power point as a teaching aid while most of them had been using different computer aided tools to enhance students' learning.

\subsubsection{Exploring the Eighth Research Question}

To what extent do university instructors encourage the student to use technology in learning and doing their assignment?

This question was included in the interviews conducted on both instructors and students. The majority of the instructors (around 60\%) asserted that they encouraged the students to use computer and the internet for finding related and up to date information for their classroom assignments or for final projects. However, some of the instructors believed that their subjects did not need any extra activities and that searching the net took a lot of time and actually waste the students' time! On the other hand, many students $(60 \%)$ asserted that their instructors didn't encourage or show any interest in technology use in and out of the class and didn't assign the students to use and search the net whereas a few students (about 8\%) claimed that their instructors had them go through the net and find new materials for the class.

\subsubsection{Exploring the Ninth Research Question}

What are the limitations, if any, in using technology in university classes?

Most of the instructors believed that technological tools were not adequate at university levels and that most of the classes were not equipped with the facilities. They believed that despite many attempts they made and the time allocated to integrating technology in the classroom, many experienced disruptions that devices can bring about leading to the negative impacts of using technology in the class. Also, they claimed that digital technology training and preparing lessons to include new technologies can be time consuming and that the instructors need some workshops to get familiar with the latest technological tools in their fields and be up to dated.

The other problem mentioned was that not all students or instructors use a computer at home or have internet access. There is a digital divide of reduced computer literacy in students from indigenous, lower socioeconomic or regional/rural backgrounds. Moreover, some of the instructors, especially older professors, did not believe in integrating technology in the classrooms pointing to different reasons such as lack of time, losing their authority in the class, and even ineffectiveness of such activities. In many cases, there was a time lapse between the time instructors were teaching and the time students received the materials. Another problem is that there is little (if any) appropriate access to technical support (in or out of the classroom), availability of infrastructure (computer labs, software), and time allocated to incorporate new technologies in most contexts.

\subsection{Observational Analysis}

In line with the study purpose, some classes were observed through the study procedure to see how much the instructors integrated technological tools in their instruction. It should be mentioned that the observation was done with the instructors' prior consent and that the classes were selected randomly from different fields of study to set the stage for better comparison. Out of 111 instructors participating in the study, thirty instructors agreed to 
have their classes observed. Therefore, 8 classes were selected considering the following criteria: the classes should contain both male and female students; there were two instructors from different fields of study (i.e. Humanity, Engineering, Art, and Basic sciences); and the number of male and female instructors was the same ( 4 male and 4 female).

The results of the observation showed that out of eight instructors, only five of them used power point in their classes most of the sessions and the other three instructors asserted that using technology was not needed in the course or it would be time consuming. However, they assigned some projects to the students to be delivered at the end of the term. In two of the classes, the video projector did not work for three sessions and it made the instructors use the board. In some other classes, there were some students who asserted that they did not have access to computer or they didn't have adequate computer literacy. In general, engineering and art instructors were more willing to use technological tools while science and humanity instructors believed that it was not that much effective. There was not a significant difference in technology use between the male and female instructors.

\section{Discussion and Conclusion}

The present study aimed to investigate the perception of university instructors and students towards technology use, their perceived and actual ICT literacy, the reasons that might encourage or discourage the application of technology in their instruction/ learning as well as the limitation they might face in this regard.

In most educational system such as Iran, instructors still prefer wiring on the board to typing and students prefer reading books and printed materials. The point is that not all the instructors believed in the effectiveness of integrating technology in the classroom which shows an urgent need for generating technology use culture among the university instructors. The findings of the study revealed that although instructors and students held different perceptions regarding their own ICT literacy they mostly agreed with the integration of technology in education. Also, the findings showed that students and instructors have different capacities and ICT skills. Some students even believed that they knew about computer skills more than their instructors in the class and that some of their instructors were not able to work with the simplest form of technology. Further, some of the instructors believed that using technological tools was a waste of time and energy because of inefficiency of the tools and inadequate class time for both training the students to work with the devices and teaching the materials simultaneously.

Moreover, it is noteworthy that technological literacy requires access to ICT improvements for classroom implementation and to keep up with continuous technological advances. This needs regular and sustainable workshops to be held for instructors to get familiar with recent technological advances in their fields. Furthermore, an online education should be accessible to all students. Some students can't afford technology tools necessary for class assignments. That's why instructors have to consider technology use as optional. If instructors are to assign students some extra activities or assignments which require technological access at home, there should be computer and internet access for all the students at any socioeconomic or regional/rural background. [16] claimed that special actions should be taken to prevent students who lack computer skills from being disadvantaged or lag behind the other students.

The major reasons limiting instructors in using ICT include lack of instructors' and/or students' ICT skills; lack of their confidence; lack of effective training; lack of suitable educational software; limited access to ICT; rigid structure of traditional education systems; etc. Teachers' integration of ICT into teaching is also influenced by organizational and institutional factors which should be considered when examining ICT integration. Factors such as institutional support as well as instructors' capability influencing the use of online learning in universities are very important.

Of course, there is no single solution that applies for every course, every instructor, or every kind of teaching. Integrating technology in the classroom is a complex process for many instructors depending on more than the devise use. First of all, it requires ICT professional development which is applicable to various circumstances instructors have to handle with different teaching experience and confidence. Also, it is important to develop a common vision regarding the role of ICT in education with stakeholders and create holistic improvements to support and train the instructors to be able to address the many issues they face; otherwise, there would be the risk of training a generation of ill-prepared students for a digital world.

Several limitations were imposed on the study. First of all, the sample was selected based on convenience sampling and thus it may not be as strong as using random sampling procedures. Second, the access to different universities was not easy. Third, the participants may have overestimated/underestimated their perceptions about their technological literacy. Thus, the validity of 
study relies on respondents' honest responses to the questionnaire. The study was restricted to university instructors and students in Islamic Azad University in Iran and the results may not reflect the full depth and breadth of computer literacy skills needed at university levels.

Numerous recent studies have established the benefits of technology use and efficacy within the educational settings in preparing students for their future. The attitude of the educator as well as the instructor towards technology use in the classroom is indicative of how well technology will be integrated in the classroom during instruction. Follow-up studies on this regard across cultures are necessary in order to find better approaches for instructors and state administrators in this age. These results will aid administrators and designers with making positive changes to professional development that both improve and increase university instructors' successful integration of technology in their classrooms. We live in a digital world, and technology is a life skill. According to NMC Horizon Report (2017), "being digitally literate is more than obtaining "isolated technological skills". Rather, it deals with creating a deeper understanding of the digital environment which, in turn, enables people to adapt to new contexts in which they can share their experiences with others.

The results of this study should also inform further research on university instructors and students' technology literacy and contribute to the related body of knowledge. Thus, the study should contribute to the shared understanding of gaps in computer readiness skills used at college and work and the implications to university course taking patterns.

\section{References}

[1] Smith, L.C., "Technology Literacy Skills Needed in Further Education and/or Work: A Delphi Study of High School Graduates' Perspectives", Unpublished Thesis, University of Florida, 2015.

[2] Catts, R., and J. Lau, Towards Information Literacy Indicators, UNESCO, Paris, 2008.

[3] Dinçer, S., "Assessing the Computer Literacy of University Graduates", The Third International Conference on Open and Flexible Education, Hong Kong, 2016.

[4] M. Wilson, and K. Scalise, "Assessment of Learning in Digital Networks". In P. Griffin and E. Care (Eds.), Assessment and Teaching of 21st Century Skills:
Methods and Approach, Dordrecht: Springer, 2015, pp. 57-81.

[5] Anderson, R., and J. Ainley, "Technology and Learning: Access in Schools Around the World". In B. McGaw, E. Baker, \& P. Peterson (Eds.), International Encyclopedia of Education (3rd ed.), Amsterdam, the Netherlands: Elsevier, 2010, pp. 21-33.

[6] D. Barr, J. Harrison, and L. Conery, "Computational Thinking: A Digital Age Skill for Everyone", Learning and Leading with Technology, 38 (6), 2011, pp. 20-23.

[7] D.M. Grant, A.D. Malloy, and M.C. Murphy, “A Comparison of Student Perceptions of Their Computer Skills to Their Actual Abilities", Journal of Information Technology Education, 8, 2009, pp.141-160.

[8] P. Wallace, and R. Clariana, "Perception versus Reality: Determining Business Students' Computer Literacy Skills and Need for Instruction in Information Concepts and Technology", Journal of Information Technology Education, 4, 2005, pp. 141-151.

[9] F. Yazdani, and S.M. Mousavi, "Identifying the Status of Information Literacy Skills of the Elementary Teachers of District 3 of Kermanshah", Academic Library and Information Research, 10(8), 2017, pp. 95108.

[10] A. Hashemi, and A. Forotan, "The Study of the Relationship between Teacher Information Technology Literacy and Elementary Students' Progress in the Science Lesson at Jam Province", The Third International Conference on Entrepreneurship, Creativity, and Innovation, Shiraz, Iran, 2017.

[11] K. Kaminski, J. Switzer, and G. Gloeckner, "Workforce readiness: A study of university students' fluency with information technology", Computers \& Education, 53, 2009, pp. 228-233. DOI:10.1016/j.compedu.2009.01.017.

[12] I. Katz, and A. Macklin, "Information and Communication Technology (ICT) Literacy: Integration and Assessment in Higher Education", Systemics, Cybernetics and Informatics, 5, 2006, pp. 50-55.

[13] G. J. Skulmoski, F.T. Hartman, and J. Krahn, "The Delphi method for graduate research", Journal of Information Technology Education, 6, 2007, pp. 1-21.

[14] A.L. Delbecq, A.H. Van de Ven, and D.H. Gustafson, "Group Techniques for Program Planning: A Guide to Nominal Group and Delphi Processes”, Group 
\& Organization Studies, 1(2), 1976, pp. 256-256. https://doi.org/10.1177\%2F105960117600100220

[15] Gray, C. D., and P.R. Kinnear, "IBM SPSS Statistics 19 Made Simple”, Psychology Press, 2012. Institute of Education Sciences, National Center for Education Statistics, "National Assessment of Educational Progress (NAEP) Technology and Engineering Literacy (TEL) Assessment”, Washington, DC: Author, 2012.

[16] T. M. Link, and R. Marz, "Computer Literacy and Attitudes Towards E-Learning Among First Year Medical Students", BMC Medical Education, 6 (1), 2006, pp. 25-34. doi: 10.1186/1472-6920-6-34. 